\title{
In Vivo Topical and Systemic Distribution Kinetics of Liposomes with Various Properties for Application to Drug Delivery Systems
}

\author{
Hisako Ibaraki ${ }^{1}$ and Takanori Kanazawa ${ }^{1,2^{*}}$ \\ ${ }^{1}$ School of Pharmacy, Tokyo University of Pharmacy and Life Sciences, \\ 1432-1, Horinouchi, Hachioji, Tokyo 192-0392, Japan \\ ${ }^{2}$ School of Pharmaceutical Sciences, University of Shizuoka, \\ 52-1, Yada, Suruga-ku, Shizuoka 422-2526, Japan
}

(Received October 1, 2021; accepted December 20, 2021; online published January 20, 2022)

Keywords: liposome, drug delivery system, biodistribution, skin application, systemic administration

Liposomes and lipid nanoparticles have been actively researched and developed as drug delivery carriers owing to their many advantages, such as high biocompatibility and degradability. Their in vivo kinetics depend on the route of administration, i.e., topical or intravenous, and their physical properties, such as particle size and surface charge. Designing liposomes that regulate in vivo kinetics and ensure efficient delivery to disease sites will result in excellent therapeutic effects. However, only a handful of studies have examined whether the characteristics and constituent lipids of liposomes can control histological and in vivo kinetics. In this review, we focus on the surface charge and polyethylene glycol (PEG) modifications of liposomes and evaluate their biodistribution. On the basis of our findings, we expound the effects of the intradermal permeability, inflammatory site accumulation, and physical properties of liposomes on systemic distribution kinetics.

\section{Introduction}

Liposomes are being studied as biological membrane models in the field of molecular biology. In 1964, when Bangham and Horne observed a suspension of lecithin (egg-yolk phosphatidylserine) with an electron microscope, they noted the formation of vesicles consisting of a bilayer membrane with a lamellar structure. ${ }^{(1)}$ This supported a biological membrane model wherein lipids have a bilayer structure with hydrophobic sites facing inward. In the following year, Bangham et al. showed that these were closed vesicles encapsulating an aqueous phase, which led to the discovery of liposomes. ${ }^{(2)}$ In 1972, Singer and Nicolson proposed a fluid mosaic model, ${ }^{(3)}$ which became the basic structure of biological membranes today. Furthermore, the discovery that liposomes can envelop drugs, have low antigenicity and toxicity, and can be metabolized in vivo has led to their possible application as carriers in drug delivery systems (DDSs). Many liposome formulations are currently available, mainly anticancer drugencapsulating liposomes, of which the most widely known is Doxil (Table 1). With the approval of the world's first siRNA drug Onpattro in 2018 and the mRNA vaccine for COVID-19 in 2021, expectations for liposomes and lipid nanoparticles have never been higher. ${ }^{(4-6)}$

*Corresponding author: e-mail: t.kanazawa@u-shizuoka-ken.ac.jp 
Table 1

Clinically approved liposomal formulations. (This table includes products that are currently discontinued.)

\begin{tabular}{|c|c|c|c|c|c|c|c|}
\hline $\begin{array}{l}\text { Liposome } \\
\text { product }\end{array}$ & $\begin{array}{c}\text { Approved } \\
\text { year }\end{array}$ & Drug & $\begin{array}{l}\text { Approved } \\
\text { indication }\end{array}$ & $\begin{array}{c}\text { Lipid } \\
\text { construction }\end{array}$ & Route & $\begin{array}{l}\text { Size } \\
(\mathrm{nm})\end{array}$ & Ref. \\
\hline \multicolumn{8}{|l|}{ For cancer treatment } \\
\hline $\begin{array}{l}\text { Doxil }{ }^{\circledR} \\
\text { (Janssen) }\end{array}$ & US 1995 & Doxorubicin & $\begin{array}{c}\text { Ovarian cancer, } \\
\text { breast cancer, } \\
\text { Kaposi's sarcoma }\end{array}$ & $\begin{array}{c}\text { HSPC/MPEG2000- } \\
\text { DSPE/cholesterol } \\
\text { (56:39:5 molar ratio) }\end{array}$ & i.v. & 100 & (32) \\
\hline $\begin{array}{l}\text { DaunoXome }{ }^{\circledR} \\
\text { (Galen) }\end{array}$ & US 1996 & Daunorubicin & $\begin{array}{l}\text { HIV-associated } \\
\text { Kaposi's sarcoma }\end{array}$ & $\begin{array}{l}\text { DSPC/cholesterol } \\
\text { (2:1 molar ratio) }\end{array}$ & i.v. & $45-80$ & (33) \\
\hline $\begin{array}{l}\text { Depocyt }{ }^{\circledR} \\
\text { (Pacira } \\
\text { Pharmaceuticals) }\end{array}$ & US 1999 & Cytarabine & $\begin{array}{l}\text { Neoplastic } \\
\text { meningitis }\end{array}$ & $\begin{array}{c}\text { DOPC/DPPG/ } \\
\text { cholesterol/triolein } \\
\text { (7:1:1:11 molar ratio) }\end{array}$ & $\begin{array}{l}\text { Traventric- } \\
\text { ular/lumbar } \\
\text { puncture }\end{array}$ & 20 & (34) \\
\hline $\begin{array}{l}\text { Myocet }{ }^{\circledR} \\
(\text { Teva UK) }\end{array}$ & EU 2000 & Doxorubicin & $\begin{array}{c}\text { Combination } \\
\text { therapy with } \\
\text { cyclophosphamide } \\
\text { in metastatic breast } \\
\text { cancer }\end{array}$ & $\begin{array}{c}\text { EPC/cholesterol } \\
\text { (55:45 molar ratio) }\end{array}$ & i.v. & 190 & (35) \\
\hline $\begin{array}{l}\text { Mepact } \AA \\
\text { (Takeda) }\end{array}$ & $\begin{array}{l}\text { US } 2004 \\
\text { EU } 2009\end{array}$ & Mifamurtide & $\begin{array}{l}\text { Osteosarcoma } \\
\text { (non-metastatic) }\end{array}$ & $\begin{array}{c}\text { DOPS/POPC } \\
\text { (3:7 molar ratio) }\end{array}$ & i.v. & - & (36) \\
\hline $\begin{array}{l}\text { Marqibo }{ }^{\circledR} \\
\text { (Spectrum) }\end{array}$ & US 2012 & Vincristine & $\begin{array}{c}\text { Acute lymphoblastic } \\
\text { leukemia }\end{array}$ & $\begin{array}{c}\text { SM/cholesterol } \\
\text { (60:40 molar ratio) }\end{array}$ & i.v. & 100 & (37) \\
\hline $\begin{array}{l}\text { Onivyde }{ }^{\circledR} \\
\text { (Merrimack } \\
\text { Pharmaceuticals) }\end{array}$ & $\begin{array}{l}\text { US } 2015 \\
\text { EU } 2016\end{array}$ & Irinotecan & $\begin{array}{l}\text { Combination therapy } \\
\text { with fluorouracil } \\
\text { and leucovorin in } \\
\text { metastatic pancreatic } \\
\text { adenocarcinoma }\end{array}$ & $\begin{array}{c}\text { DSPC/cholesterol/ } \\
\text { MPEG-2000-DSPE } \\
\text { (3:2:0.015 molar } \\
\text { ratio) }\end{array}$ & i.v. & $80-140$ & (38) \\
\hline $\begin{array}{l}\text { Vyxeos }{ }^{\circledR} \\
\text { (Celator } \\
\text { Pharmaceuticals) }\end{array}$ & $\begin{array}{l}\text { US } 2017 \\
\text { EU } 2018\end{array}$ & $\begin{array}{l}\text { Daunorubicin/ } \\
\text { cytarabine }\end{array}$ & $\begin{array}{l}\text { Acute myeloid } \\
\text { leukemia (t-AML), } \\
\text { AML with } \\
\text { myelodysplasia- } \\
\text { related changes } \\
\text { (AML-MRC) }\end{array}$ & $\begin{array}{c}\text { DSPC/DSPG/ } \\
\text { cholesterol }(7: 2: 1) ; \\
\text { daunorubicin/ } \\
\text { cytarabine }(5: 1)\end{array}$ & i.v. & 100 & (38) \\
\hline \multicolumn{8}{|c|}{ Analgesics/anesthesia } \\
\hline $\begin{array}{l}\text { Diprivan }{ }^{\circledR} \\
\text { (Fresenius Kabi) }\end{array}$ & US 1989 & Propofol & $\begin{array}{c}\text { Induction and } \\
\text { maintenance of } \\
\text { sedation/anesthesia }\end{array}$ & $\begin{array}{l}\text { Egg yolk and } \\
\text { cholesteryl sulfate } \\
\text { complex }\end{array}$ & i.v. & - & (39) \\
\hline $\begin{array}{l}\text { DepoDur } \\
\text { (Pacira } \\
\text { Pharmaceuticals ) }\end{array}$ & US 2004 & $\begin{array}{l}\text { Morphine } \\
\text { sulfate }\end{array}$ & Pain management & $\begin{array}{l}\text { DOPC, DPPG, } \\
\text { cholesterol, and } \\
\text { triolein }\end{array}$ & Epidural & $\begin{array}{l}17000- \\
23000\end{array}$ & (40) \\
\hline $\begin{array}{l}\text { Exparel }{ }^{\circledR} \\
\text { (Pacira } \\
\text { Pharmaceuticals ) }\end{array}$ & US 2011 & Bupivacaine & Pain management & $\begin{array}{l}\text { DEPC, DPPG, } \\
\text { cholesterol, and } \\
\text { tricaprylin }\end{array}$ & $\begin{array}{c}\text { Local } \\
\text { anesthesia }\end{array}$ & $\begin{array}{l}3000- \\
30000\end{array}$ & (41) \\
\hline \multicolumn{8}{|c|}{ Age-related macular degeneration treatment } \\
\hline $\begin{array}{l}\text { Visudyne }{ }^{\circledR} \\
\text { (Bausch and Lomb) }\end{array}$ & $\begin{array}{l}\text { US } 2000 \\
\text { EU } 2000\end{array}$ & Verteporfin & $\begin{array}{l}\text { Choroidal neo- } \\
\text { vascularization }\end{array}$ & $\begin{array}{c}\text { DMPC/EPG } \\
\text { (1:8 molar ratio) }\end{array}$ & i.v. & 100 & $(36)$ \\
\hline \multicolumn{8}{|c|}{ Nanoparticles for fungal treatments } \\
\hline $\begin{array}{l}\text { Abelcet }{ }^{\circledR} \\
\text { (Sigma-Tau } \\
\text { Pharmaceuticals) }\end{array}$ & US 1995 & $\begin{array}{c}\text { Amphotericin } \\
\text { B }\end{array}$ & $\begin{array}{l}\text { Invasive severe } \\
\text { fungal infections }\end{array}$ & $\begin{array}{l}\text { DMPC:DMPG } \\
\text { (7:3 molar ratio) }\end{array}$ & i.v. & $\begin{array}{l}600- \\
11000\end{array}$ & $(36)$ \\
\hline $\begin{array}{l}\text { Amphotec }{ }^{\circledR} \\
\text { (Ben Venue } \\
\text { Laboratories Inc.) }\end{array}$ & US 1996 & $\begin{array}{c}\text { Amphotericin } \\
\text { B }\end{array}$ & $\begin{array}{l}\text { Severe fungal } \\
\text { infections }\end{array}$ & $\begin{array}{c}\text { HSPC/DSPG/ } \\
\text { Cholesterol } \\
\text { (2:0.8:1 molar ratio) }\end{array}$ & i.v. & 100 & $(42)$ \\
\hline $\begin{array}{l}\text { AmBisome }{ }^{\circledR} \\
\text { (Gilead Sciences) }\end{array}$ & US 1997 & $\begin{array}{c}\text { Amphotericin } \\
\text { B }\end{array}$ & $\begin{array}{l}\text { Aspergillus, } \\
\text { Candida, and/ } \\
\text { or Cryptococcus } \\
\text { species infections } \\
\text { (secondary) }\end{array}$ & $\begin{array}{c}\text { D-Lin-MC3-DMA / } \\
\text { PEG2000-C-DMG/ } \\
\text { DSPC/cholesterol }\end{array}$ & i.v. & $<100$ & (43) \\
\hline
\end{tabular}


Table 1 (Continued)

Clinically approved liposomal formulations. (This table includes products that are currently discontinued.)

\begin{tabular}{|c|c|c|c|c|c|c|c|}
\hline $\begin{array}{l}\text { Liposome } \\
\text { product }\end{array}$ & $\begin{array}{l}\text { Approved } \\
\text { year }\end{array}$ & Drug & $\begin{array}{l}\text { Approved } \\
\text { indication }\end{array}$ & $\begin{array}{c}\text { Lipid } \\
\text { construction }\end{array}$ & Route & $\begin{array}{l}\text { Size } \\
(\mathrm{nm})\end{array}$ & Ref. \\
\hline \multicolumn{8}{|l|}{ RNAi therapeutics } \\
\hline $\begin{array}{l}\text { Onpattro }{ }^{\circledR} \\
\text { (Alnylam } \\
\text { Pharmaceuticals) }\end{array}$ & $\begin{array}{l}\text { US } 2018 \\
\text { EU } 2018\end{array}$ & $\begin{array}{l}\text { Patisiran (anti- } \\
\text { Transthyretin } \\
\text { siRNA) }\end{array}$ & $\begin{array}{l}\text { Transthyretin } \\
\text { (TTR)-mediated } \\
\text { amyloidosis }\end{array}$ & $\begin{array}{c}\text { D-Lin-MC3-DMA / } \\
\text { PEG2000-C-DMG/ } \\
\text { DSPC/cholesterol }\end{array}$ & i.v. & - & (44) \\
\hline \multicolumn{8}{|l|}{ Vaccines } \\
\hline $\begin{array}{l}\text { Epaxal }{ }^{\circledR} \\
\text { (Crucell) }\end{array}$ & US 1993 & $\begin{array}{c}\text { Inactivated } \\
\text { hepatitis A } \\
\text { virus (strain } \\
\text { RGSB) }\end{array}$ & Hepatitis A & $\begin{array}{c}\mathrm{DOPC} / \mathrm{DOPE}(75: 25 \\
\text { molar ratio) }\end{array}$ & i.m. & 150 & (45) \\
\hline $\begin{array}{l}\text { Inflexal } \mathrm{V}( \\
\text { (Crucell, Berna } \\
\text { Biotech) }\end{array}$ & US 1997 & $\begin{array}{c}\text { Inactivated } \\
\text { hemaglutinine } \\
\text { of influenza } \\
\text { virus strains A } \\
\text { and B }\end{array}$ & Influenza & $\begin{array}{c}\mathrm{DOPC} / \mathrm{DOPE}(75: 25 \\
\text { molar ratio) }\end{array}$ & i.m. & 150 & (46) \\
\hline $\begin{array}{l}\text { Spikevax }{ }^{\circledR} \\
\text { (Moderna) }\end{array}$ & $\begin{array}{l}\text { US } 2021 \\
\text { EU } 2021\end{array}$ & $\begin{array}{l}\text { mRNA active } \\
\text { substance that } \\
\text { encodes the } \\
\text { pre-fusion } \\
\text { stabilized spike } \\
\text { glycoprotein } \\
\text { of } 2019 \text { novel } \\
\text { coronavirus } \\
\text { (SARS-CoV-2) }\end{array}$ & COVID-19 & $\begin{array}{l}\text { PEG2000-DMG/ } \\
\text { DSPC/ cholesterol }\end{array}$ & i.m. & $80-160$ & (47) \\
\hline $\begin{array}{l}\text { Comirnaty }{ }^{\circledR} \\
\text { (Pfizer and } \\
\text { BioNTech) }\end{array}$ & $\begin{array}{l}\text { US } 2021 \\
\text { EU } 2021\end{array}$ & $\begin{array}{l}\text { Tozinameran } \\
\text { (mRNA active } \\
\text { substance that } \\
\text { encodes the } \\
\text { pre-fusion } \\
\text { stabilized spike } \\
\text { glycoprotein } \\
\text { of } 2019 \text { novel } \\
\text { coronavirus } \\
\text { (SARS-CoV-2)) }\end{array}$ & COVID-19 & $\begin{array}{c}\text { ALC-0315/ALC- } \\
\text { 0159/DSPC/ } \\
\text { cholesterol }\end{array}$ & i.m. & $80-100$ & (48) \\
\hline
\end{tabular}

HSPC: L- $\alpha$-phosphatidylcholine (soybean, hydrogenated), MPEG2000-DSPE: N(carbonyl-methoxypolyethylene glycol 2000)-1,2-distearoyl-sn-glycerol-3-phosphoethanolamine sodium salt, DSPC: 1,2-distearoyl-sn-glycero-3-phosphocholine, DOPC: 1,2-dioleoyl-sn-glycero-3-phosphocholine, DPPG: 1,2-dipalmitoyl-sn-glycero-3-phospho-(1'-rac-glycerol), EPC: egg phosphatidylcholine, DOPS: 1,2-dioleoyl-sn-glycero-3-phospho-L-serine,POPC: 1-palmitoyl-2-oleoyl-glycero-3-phosphocholine, SM: sphingomyelin, DEPC: 1,2-dierucoyl-sn-glycero-3-phosphocholine, DMPC: 1,2-dimyristoyl-sn-glycero-3-phosphocholine, EPG: L- $\alpha$-phosphatidylglycerol (egg, chicken), DMPG: 1,2-dimyristoyl-sn-glycero-3-phospho-(1'-rac-glycerol), D-Lin-MC3DMA: 4-(dimethylamino)-butanoic acid, (10Z,13Z)-1-(9Z,12Z)-9,12-octadecadien-1-yl-10,13-nonadecadien-1-yl ester, PEG2000C-DMG: 1,2-dimyristoyl-rac-glycero-3-carbonylaminoethyl- $\omega$-methoxypolyethylene glycol-2000, DOPE: 1,2-dioleoyl-snglycero-3-phosphoethanolamine, SM-102: 9-heptadecanyl 8-\{(2-hydroxyethyl)[6-oxo-6-(undecyloxy)hexyl]amino $\}$ octanoate, PEG2000-DMG: 1,2-dimyristoyl-rac-glycero-3-methoxypolyethylene glycol-2000 powder, ALC-0159: 2-[(polyethylene glycol)2000]-N,N-ditetradecylacetamide, ALC-0315: ((4-idrossibutil)azanediil)bis(esano-6,1-diil)bis(2-esildecanoate)

In terms of targeted delivery and pharmacological activity on intravenous and topical administration, liposome preparations are superior to drugs alone. ${ }^{(7)}$ Liposomes are widely used for intravenous administration; at the laboratory level, topical administration, such as dermal, oral, pulmonary, or ocular administration, not only exhibits a pharmacological effect but also is useful in improving the patient's quality of life and medication compliance and reducing side effects. ${ }^{(8-11)}$ Liposomes for oral or pulmonary administration are mainly carriers for peptide and 
poorly absorbable drugs. The gastrointestinal transit time of insulin after oral administration is increased by modifying the liposome surface with chitosan, which has high affinity for gastrointestinal mucosa. Drug-encapsulating, mucosa-adherent component-modified liposomes have persistent pharmacological activity in the lungs on pulmonary administration, owing to the large effective surface area, similar to that in the gastrointestinal tract, albeit with lower levels of proteolytic enzymes in the lungs than in the gastrointestinal tract. ${ }^{(12,13)}$ Water-soluble substances with low affinity for the skin and those with high degradability can be encapsulated in liposomes; liposomes offer several advantages, such as allowing penetration by improving skin affinity and enhancing the moisturizing effect possessed by phospholipids themselves. These advantages have raised expectations in terms of dermal administration of liposomes. ${ }^{(14-16)}$

Liposomes are currently widely used as DDSs or carriers for systemic administration, mainly through the intravascular/intravenous routes. For a drug to function in vivo after intravenous administration, it is important to control its stability and systemic distribution in blood. When liposomes are intravenously administered, their half-life in blood is longer when the particles are smaller. Hard liposomes made of saturated phospholipids have a longer half-life and a higher blood stability than liposomes made of unsaturated phospholipids. The acyl chain on the phospholipid length is also an important factor in controlling the liposomal physical properties, and the constituent lipids and physical properties of liposomes affect their systemic distribution after intravenous administration. ${ }^{(17,18)}$ In addition to improving blood retention by altering physicochemical properties to avoid phagocytosis by the reticular endothelial system (RES), polyethylene glycol (PEG) modification for designing stealth liposomes has now become an indispensable technique, especially to deliver anticancer drugs. ${ }^{(19,20)}$ Since cancer tissue rapidly undergoes angiogenesis and has high vascular permeability, polymer substances and liposomes that do not leak into normal tissue permeate the vascular wall around the cancer tissue. Furthermore, since the lymph tissue is immature, it is difficult to maintain the liposomes that have permeated, and they passively accumulate in the tumor tissue. This phenomenon is called the enhanced permeation and retention (EPR) effect, and PEG liposomes that accumulate in the tumor due to this EPR effect significantly reduce the opsonin effect in the blood, thus bypassing the RES. By remaining in the blood for a long time, the number of times a liposome passes around the tumor blood vessel increases, improving the accumulation in the tumor tissue by passive targeting. ${ }^{(21,22)}$ In addition, in the inflamed area, chemical mediators such as histamine increase the permeability of capillaries and the infiltration of macrophages. Liposomes and polymers can selectively migrate from blood vessels to the inflamed area, thus passively targeting the inflamed area. ${ }^{23,24)}$ On the basis of clinical studies on inflammatory diseases, amphotericin B liposomes are believed to suppress renal failure when they accumulate in the inflamed area, resulting in changes in in vivo kinetics (inhibition of renal distribution) and passive targeting.(25)

Therefore, liposomes can be modified with ligands for specific receptors and antibodies against specific cells to confer active targeting. Furthermore, liposomes that release drugs in response to certain triggers, such as ultrasound, heat, light, $\mathrm{pH}$, and enzymes, are also being developed. ${ }^{(26-29)}$ Thus, in vivo kinetics after the local and intravenous administration of liposomes can be controlled by modifying the physical properties of liposomes. In this review, 
we elucidate the effects of the physical properties of liposomes on intradermal permeability after they are topically administered. ${ }^{(30)}$ We also elucidate these effects on the distribution kinetics in the inflamed area after liposomes are intravenously administered. ${ }^{(31)}$

\section{Types and Composition of Lipids that Affect the Physical Characteristics of Liposomes}

Liposomes are spherical vesicles having phospholipid bilayers that are biocompatible, degradable, have high affinity for skin membranes, ${ }^{(48)}$ and have the ability to encapsulate drugs and control their physical properties by controlling the lipid composition. The properties of liposomes under physiological conditions are determined from the physicochemical properties of the hydrophilic head and hydrophobic fatty acid tail of the constituent lipids. The hydrophilic group of the lipid affects the charge and molecular structure of the liposome, whereas the hydrophobic group of the lipid determines the particle size and flexibility of the liposome from the relative differences in the type of fatty acid, the length of the hydrocarbon chain, and the number of double bonds (degree of unsaturation).

Glycerophospholipids are generally building blocks of liposomes. Dimyristoyl PC (DMPC), dipalmitoyl PC (DPPC), and distearyl PC (DSPC), with phase transition temperatures equivalent to or above room temperature, are commonly used for preparing liposomes. Phosphatidylethanolamine (PE) and phosphatidylcholine (PC) have similar molecular structures at first glance, but in an aqueous solution, they form very different molecular assemblies. From a structural standpoint, the hydrophilic group of PE is volumetrically smaller than that of PC. ${ }^{(50)}$ The polar and non-polar portions are well balanced in PC and form a stable bilayer in an aqueous medium, called a cylinder-type lipid.

In contrast, in lipids with unsaturated acyl groups, such as DOPE, the volume ratio between the polar and non-polar components of the molecule affects the liposomal particle formation and structure in water. Unsaturated PEs called cone-type lipids have strong tendency to form a hexagonal II structure, a non-bimolecular membrane structure at neutral $\mathrm{pH}$, because the polar region is much smaller than the non-polar region. ${ }^{(51)}$ These lipids are generally unable to spontaneously form liposomes under physiological conditions, but when mixed with amphiphilic molecules with carboxyl groups, such as cholesteryl hemi-succinate (CHEMS), the carboxyl groups dissociate and ionize, stabilizing the lamellar structure. Subsequently, the ionized carboxyl groups hydrate the surface of the unsaturated PE membrane and suppress the interaction between lipid membranes through charge repulsion. ${ }^{(52)}$

Therefore, DOPE/CHEMS liposomes, when combined with CHEMS, form a stable lamellar phase at physiological $\mathrm{pH}$ and exhibit a negative charge; DOPE/CHEMS liposomes are $\mathrm{pH}$ sensitive, and DOPE is also used as a membrane fusion lipid and a helper lipid for the endosome escape of drugs. ${ }^{(53,54)}$ In addition, PE can be modified to ethanolamine, a hydrophilic moiety, making the modification of polyethylene glycol and maleimide easier. In terms of surface charge, PC and PE lipids are neutral because they have one cationic charge and one anionic charge in their molecule. Cationic lipids are composed of two acyl or alkyl groups and a quaternary amine. Recently, there have been many reports of cationic lipids with tertiary amines 
that transition from neutral to cationic in a $\mathrm{pH}$-dependent manner. The $\mathrm{pH}$ inside the endosome decreases from the early endosomes to $5.0-5.5$ in the late endosomes. ${ }^{(55)}$ In response to this acidic environment, tertiary amines undergo protonation, which triggers interaction with the endosomal membrane, resulting in membrane fusion or disruption, and finally escape from the endosome. A pH-responsive lipid (D-Lin-MC3-DMA) was designed using the same technology as that used to formulate Onpattro ${ }^{\circledR}$, the world's first siRNA drug. ${ }^{(5)}$ Phosphatidylserine (PS), phosphatidic acid (PA), and phosphatidylglycerol (PG) are used for anionic lipids. Other than glycerophospholipids, sphingomyelin lipids, such as ceramides, have been applied in cosmetics.

Cholesterol contributes to the membrane properties of a bilayer composed of phospholipids. A bilayer composed of unsaturated lipids is generally fluid; however, adding cholesterol decreases fluidity.

\section{Topical Delivery of Liposomes Across the Skin}

\subsection{Dermal drug delivery route and typical DDS}

Dermal administration is an attractive route because it improves the patient's quality of life and compliance. However, drugs must have a molecular weight (MW) of less than 500 daltons to penetrate the skin, ${ }^{(56)}$ and high-molecular-weight drugs cannot diffuse out of the stratum corneum or tight junction barrier of the epidermis and thus are unable to effectively penetrate the skin. ${ }^{(56)}$ Drugs suitable for transdermal administration must have low melting points and molecular weights and be lipophilic. ${ }^{(56,58)}$ Microneedles, iontophoresis, and sonophoresis have been studied as ways to improve drug delivery through the skin. ${ }^{(53-61)}$ However, these physical methods have raised concerns owing to the damage and toxicity caused to the skin or other organs. Recent studies have validated and focused on the use of nanocarriers, such as niosomes, transfersomes, ethosomes, peptide complexes, and liposomes, for non-invasive dermal application. ${ }^{(61-65)}$

The common drug delivery mechanisms underlying dermal administration are intercellular (paracellular), transcellular, and appendageal transport pathways. ${ }^{(66,67)}$ Among them, the intercellular route is widely recognized as the main penetration route for most compounds, including liposomes. To facilitate skin penetration, liposomes or lipid nanoparticles adhere to the skin surface, increase the water content, gradually loosen the skin structure, change polarity, and finally fluidize. ${ }^{(68)}$ Additionally, some vesicles are capable of intradermal delivery in their intact state. ${ }^{(69)}$ Liposomes with a diameter of $31-41 \mathrm{~nm}$ are highly permeable. ${ }^{(70)}$ On the basis of these findings, we suggest that the intradermal administration of liposomes could enhance the utilization of the paracellular route and improve drug delivery. In this section, we introduce the topical delivery of liposomes across the skin on the basis of our works.

\subsection{Effects of physical properties of liposomes on skin permeability}

Atopic dermatitis is an intractable skin inflammatory disease in which the surface barrier of the skin is weakened or destroyed. ${ }^{(71)}$ It is extremely burdensome for patients and requires novel 
treatments. In our previous study, we explored the properties of liposomes with good permeability and their activity on skin with a weakened stratum corneum barrier as a means of treating this allergy. At present, few studies have examined the physical properties of liposomes with excellent intradermal permeability. We also prepared several liposomes using lipids with unsaturated DO groups and 18 carbon chains, and confirmed their intradermal permeability in our previous study. ${ }^{(29)}$ The surface charge of liposomes depends on the head group of phospholipids. DOTAP (positively charged lipid), DOPC (neutral charged lipid), DOPS (negatively charged lipid), and DOPE (cone-type lipid), three types of DOPC-based liposomes with different surface charges and one DOPE-based liposome with different structures, were prepared using the Bangham method, and their physical properties and intradermal permeability were researched. ${ }^{(29)}$

Their physical properties were measured by the Zetasizer Nano system (Malvern Panalytical, UK); the diameter of these four liposomes was approximately $50 \mathrm{~nm}$. The size of the vesicles has a significant impact on the efficacy of the DDS. To some extent, vesicles with diameters less than $300 \mathrm{~nm}$ can deliver their inclusions into deeper layers of the skin. ${ }^{(72,73)}$ Liposomes with an average diameter of less than $100 \mathrm{~nm}$ may be able to deliver drugs through the skin, ${ }^{(74)}$ and the paracellular width is approximately $20-80 \mathrm{~nm} .{ }^{(75,76)}$ The liposomes in Fig. 1 may be able to penetrate through the paracellular route. Cationic liposomes showed a significantly higher penetration than neutral and anionic liposomes into the skin after $5 \mathrm{~h}$ [Fig. 1(a)]. Neutral liposomes showed less fluorescence than other liposomes in deeper regions. Anionic liposomes showed a lower level of penetration than the cationic liposomes, although deeper penetration was observed after $10 \mathrm{~h}$. DOPE/CHEMS liposomes showed a consistently high intradermal delivery rate, especially $10 \mathrm{~h}$ after administration. This phenomenon may be due to the flexibility of DOPE/CHEMS liposomes.

Figure 1(b) shows the average brightness of fluorescence calculated from images observed under a confocal laser microscope $10 \mathrm{~h}$ after the dermal administration of the liposomes to a tape-stripped mouse. Anionic DOPC-based liposomes penetrated deeper than neutral liposomes, and the fluorescence of neutral and anionic liposomes decreased with increasing depth of the skin. Cationic liposomes showed strong fluorescence deep in the skin, but are considered to be damaging to the skin. Thus, the dermal delivery ability was in the order cationic $>$ anionic $>$ neutral DOPC-based liposomes. In addition, DOPE/CHEMS liposomes remained at the target site at a higher concentration than cationic liposomes after $5 \mathrm{~h}$. The lipid lamellae of the stratum corneum contain many anionic lipids that interact electrostatically with cationic particles. In general, the skin tissue is anionic and attracts cationic liposomes. Some studies have reported an increased permeability of cationic liposomes in the skin. ${ }^{(77,78)}$

In other studies, anionic DOPC-based liposomes showed a higher intradermal migration than neutral liposomes. Furthermore, negatively charged vesicles exhibit higher fluxes, enhancing drug accumulation in the superficial layers of the skin. ${ }^{(79,80)}$ Anionic vesicles have high stability and consequently improved permeability depending on the drug encapsulated. Anionic liposomes are found in topical skin care products, and we hypothesize that the electrostatic repulsion between the anionic liposomes and the skin contributed to the intradermal permeability. Furthermore, the high affinity of PS for immune-competent cells ${ }^{(81)}$ is related to its uptake and ability to remain in the skin. 


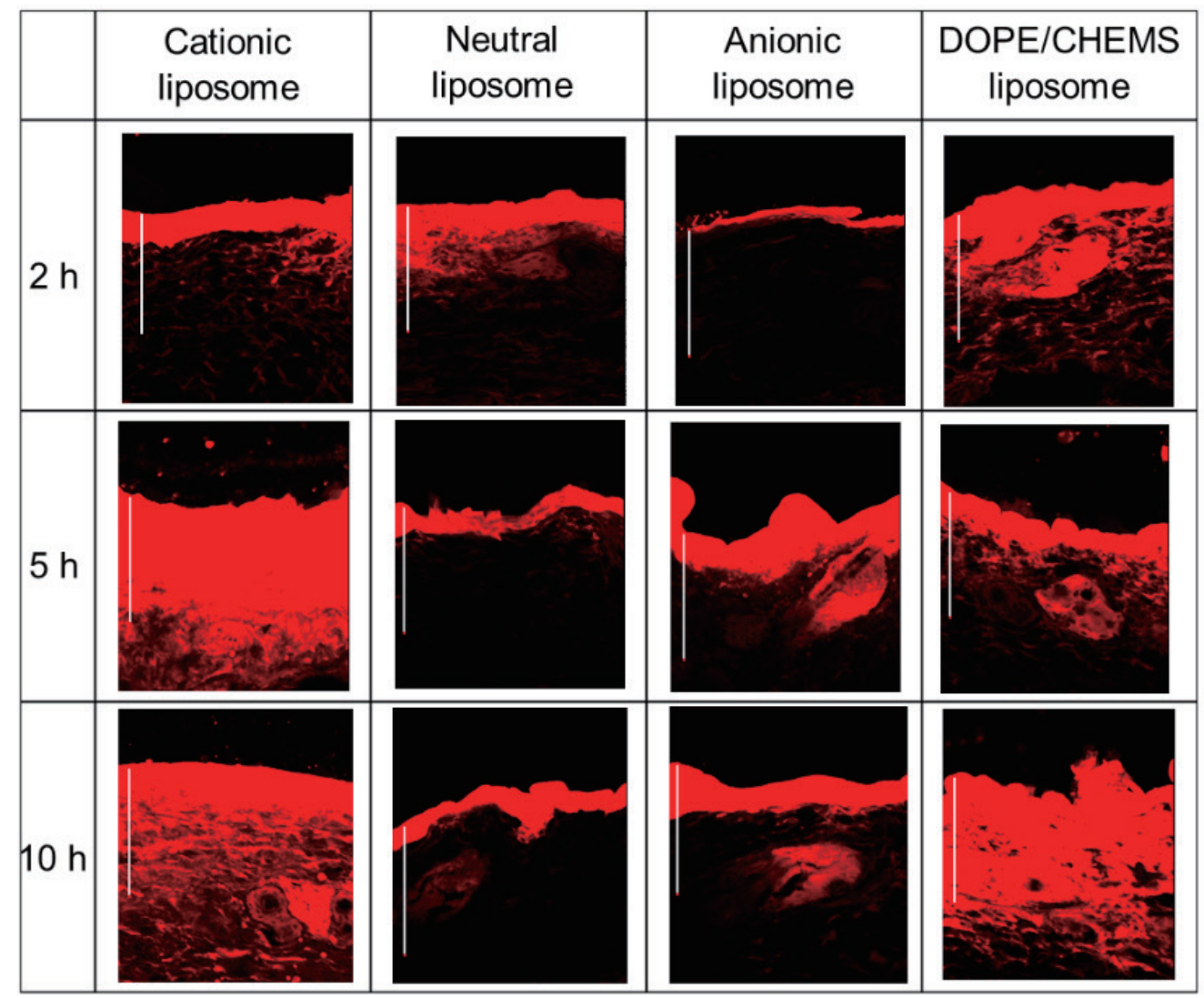

(a)

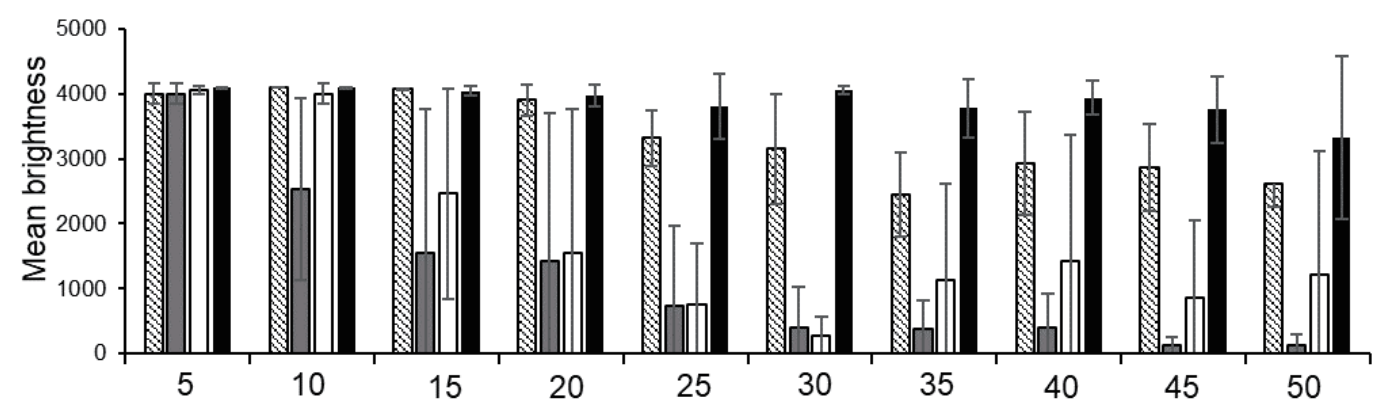

(b)

Fig. 1. (Color) Penetration ability and brightness of each liposome in tape-stripped mouse skin. (a) $1 \mu$ mol of each of DOPC-based and DOPE/CHEMS liposomes was applied to tape-stripped mouse skin. Fluorescence was observed with a confocal laser scanning microscope 2, 5, and $10 \mathrm{~h}$ after skin application. Scale bar: $100 \mu \mathrm{m}$. Magnification: $\times 600$. (b) Brightness of fluorescein-labeled liposomes in tape-stripped mouse skin. ATTO-DOPE brightness was measured at a depth of 5-50 $\mu \mathrm{m}$ from the skin surface $10 \mathrm{~h}$ after application under a confocal laser microscope based on the images in (a). Each bar represents mean \pm S.D. $(n=3)$. Figure published in "Effects of surface charge and flexibility of liposomes on dermal drug delivery," J. Drug Deliv. Sci. Technol., 50, 155-162 (2019), Hisako Ibaraki and Takanori Kanazawa et al. ${ }^{(30)}$, Copyright Elsevier (2021). 
The high flexibility of DOPE/CHEMS liposomes can explain their effectiveness in dermal drug delivery. Cevc and coworkers developed a flexible lipid carrier, the transfersome. The passage of flexible lipid nanoparticles through the skin is passively driven by osmotic pressure (also called hydration force), which forms a water gradient. ${ }^{(82,83)}$ Furthermore, flexible liposomes can pass through the skin without rupturing. ${ }^{(84)}$ Therefore, it is suggested that transfersomes or flexible liposomes can be transported more efficiently than conventional nano-lipid carriers. Conventional liposomes do not deform; they often stop at the surface of the epidermis in the intercellular pathway. The relatively high intradermal water content in the deeper layers of the skin allows liposomes to easily enter the intercellular spaces of the dermis.

There are some reports that cationic flexible liposomes improve drug penetration into the skin. ${ }^{(85,86)}$ However, there are safety concerns associated with the administration of cationic liposomes. In contrast, it is also reported that anionic flexible liposomes improve skin permeability. ${ }^{(87)}$ Indeed, the skin permeability of non-toxic, anionic, and flexible DOPE/ CHEMS liposomes is similar to that of DOPC-based cationic and DOPC-based anionic liposomes, but the flexible DOPE/CHEMS liposomes showed higher permeability, suggesting that flexibility is a more important factor than surface charge for effective skin penetration using liposomes. In addition, the particle size of liposomes was smaller than the paracellular width, suggesting that all liposomes were evenly distributed. DOPE/CHEMS liposomes showed a higher intradermal migration than conventional DOPC-based liposomes, suggesting that the flexibility of DOPE/CHEMS liposomes is the driving force underlying their successful delivery to the deeper layers of the skin. At present, we are comparing the permeability of anionic flexible liposomes and their mechanism with those of cationic and neutral flexible liposomes.

In summary, the surface charge and flexibility of liposomes are strongly related to their deliverability to the deep intradermal region. However, the exact mechanism of skin permeation is still unclear and further experiments are needed.

\subsection{Skin irritation due to liposomes of various surface charges}

To confirm the safety of liposome administration, a CCK-8 assay was performed for each liposome using a 3D human skin epidermis cultured in vitro with an immature stratum corneum. The relative values were calculated with the control (untreated) groups set at $100 \%$. DMSO was used as the control owing to its high intracutaneous permeability and cytotoxicity. ${ }^{(88)}$ As shown in Fig. 2, cationic liposomes indicated a significantly higher irritation than other liposomes, whereas neutral or anionic DOPC-based and DOPE/CHEMS liposomes showed no skin irritation.

From the results in Figs. 1 and 2, we speculate that skin irritation due to cationic liposomes is associated with the irreversible disruption of tight junctions in skin tissue and epidermal cytotoxicity due to strong electrostatic interactions caused by higher cationic charges. The balance between skin permeability and toxicity confirmed the superiority of DOPE/CHEMS liposomes for transdermal administration over flexibility. Therefore, neutral or anionic liposomes are most suitable for dermal application. 


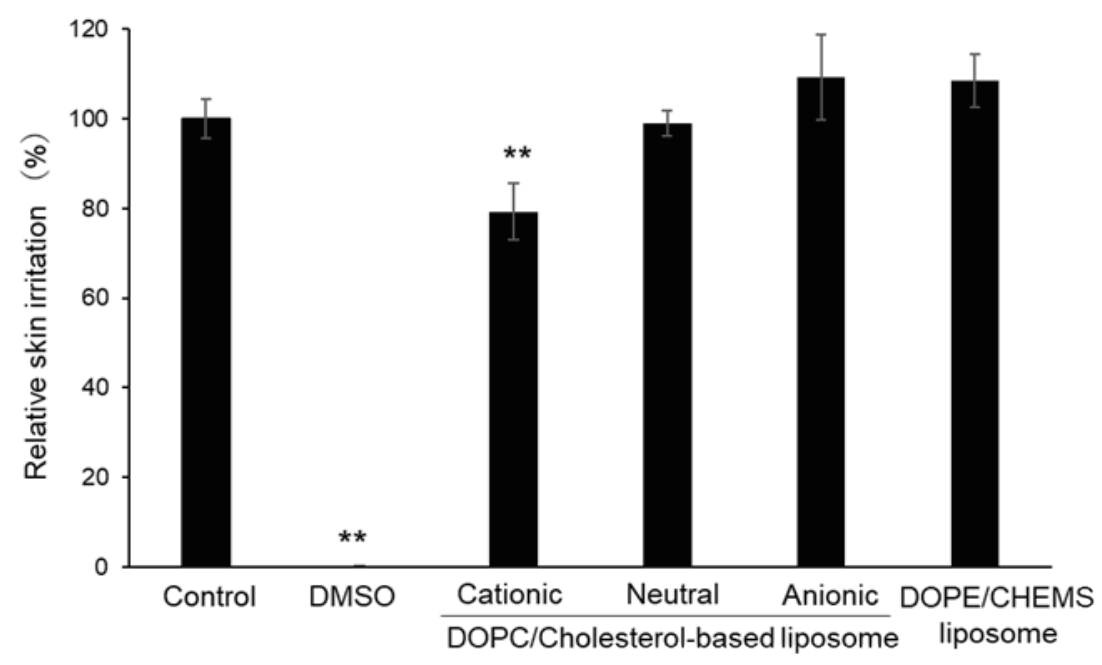

Fig. 2. Evaluation of skin irritation induced by liposomes in a 3D human epidermal cultured skin model. Skin damage after each liposome application was predicted using a 3D skin model that mimics human epidermal keratinocytes. DMSO was the positive control. $1 \mu \mathrm{mol}$ of liposomes with three different physical properties was added to a skin tissue culture cup and cell viability after $4 \mathrm{~h}$ was measured by MTT assay. Each bar represents mean \pm S.D. $(n=3) .{ }^{* *} p<0.01$ vs control group. Figure published in "Effects of surface charge and flexibility of liposomes on dermal drug delivery," J. Drug Deliv. Sci. Technol., 50, 155-162 (2019), Hisako Ibaraki and Takanori Kanazawa et al. (Ref. 30)., Copyright Elsevier (2021).

These results suggest that surface charge and flexibility are important factors affecting the intradermal permeability of liposomes, and DOPE/CHEMS liposomes are most useful in terms of permeability and toxicity.

\section{Systemic and Targeted Delivery of Liposomes to Inflamed Region}

\subsection{Typical DDS for inflammatory diseases}

Inflammatory diseases include allergic diseases, such as atopic dermatitis and asthma, and autoimmune diseases, such as rheumatoid arthritis (RA), inflammatory bowel disease (IBD), and myasthenia gravis. There are more than 80 chronic conditions that fall under autoimmune diseases and affect about $5 \%$ of the population; their incidence and prevalence are increasing. ${ }^{(89)}$ Autoimmune diseases are characterized by an immune response that damages or impairs a specific or multiple organs or tissues. The etiology of autoimmune diseases is still unknown, and the treatment of autoimmune diseases, such as RA and ulcerative colitis, is limited to symptomatic treatment with corticosteroids and immunosuppressive drugs, which significantly reduces the quality of life. ${ }^{(90,91)}$ Currently, disease-modifying anti-rheumatic drugs (DMARDs) and non-steroidal anti-inflammatory drugs (NSAIDs) are used for RA, and 5-aminosalicylic acid (5-ASA) and corticosteroids are used for ulcerative colitis. For ulcerative colitis, the administration of 5-ASA and corticosteroids is standard therapy. In recent years, the treatment for these diseases has improved with the introduction of infliximab (Remicade ${ }^{\circledR}$, Janssen 
Pharmaceutical Co., Ltd., USA) and vedolizumab (Entyvio ${ }^{\circledR}$, Takeda Pharmaceutical Company Limited, Osaka, Japan), which are anti-human TNF- $\alpha$ monoclonal antibodies. ${ }^{(92-94)}$ However, biological antibody drugs are expensive and require time and labor; furthermore, serious side effects are still a major problem. ${ }^{(95,96)}$ Therefore, the development of new formulations using nanoparticles and nanotechnology, such as liposomes, has been attracting much attention. ${ }^{(97-99)}$

Nanotechnology is attracting interest as it is opening doors for new treatment methods for autoimmune inflammatory diseases, such as RA and ulcerative colitis. It has also been applied in diagnosis and prognosis prediction, and is expected to improve the therapeutic efficacy of diseases. Not only antibody drugs, which are the standard for treating serious diseases, but also nucleic acid drugs, such as siRNA, antisense oligonucleotides, miRNA, and aptamer using RNA interference, have now become novel drug modalities for inflammatory diseases. ${ }^{(100,101)}$

The intravenous administration of drug-encapsulated nanoparticles, such as liposomes, polymeric micelles, dendrimers, and exosomes, promotes active or passive accumulation in target tissues and thus improves therapeutic efficacy and reduces side effects. ${ }^{(18,27-30,54)}$ However, few studies have comprehensively analyzed the physical properties and characteristics of nanoparticles that contribute to accumulation and the therapeutic effects on intravenous administration.

The physicochemical properties of nanoparticles are closely related to their pharmacokinetics and tissue accumulation levels. ${ }^{(102)}$ Since vascular permeability is observed in the acute phase of inflammation and angiogenesis is observed in the chronic phase, the EPR effect plays a central role in the delivery of anticancer nanomedicine. The EPR effect can also be observed at the inflammation site. Recently, the EPR effect was also confirmed to play a role in pulmonary arterial hypertension and IBD models. ${ }^{(103,104)}$ In this section, we introduce the systemic delivery of liposomes to the inflamed region on the basis of our works.

\subsection{Controlling physical properties of liposomes to provoke accumulation at inflammatory sites}

The intravenous administration of nanoparticles, such as liposomes, nano-micelles, and dendrimers, is effective in treating inflammatory diseases. ${ }^{(105,106)}$ Liposomes are widely used because of their low immunogenicity and the ease with which their surface properties can be tailored. The physicochemical properties of liposomes extend the advantage of passive targeting through the leaky vasculature of inflamed tissues. The passive targeting ability of liposomes and nanocarriers is believed to be mainly dependent on the blood circulation time, which is affected by the hydrophobicity, size, and surface charge of the vesicles. ${ }^{(107-110)}$

We previously reported four types of liposomes, PEG-cationic, PEG-anionic, cationic, and anionic liposomes, prepared using a thin film method and evaluated their accumulation at the inflammatory site. ${ }^{(30)}$ In general, nanoparticles with a diameter greater than $200 \mathrm{~nm}$ have decreased retention in blood after intravenous administration and increased accumulation in the spleen. Therefore, they are readily recognized by the RES. ${ }^{(111)}$ Similarly, the surface charge of liposomes plays an important role in their recognition by immune cells and uptake by the RES. ${ }^{(22)}$ Furthermore, inflammation in RA results in submicron-sized gaps in the synovial 
endothelial vascular cells. ${ }^{(112)}$ Therefore, given their size, the four liposomes discussed here are expected to accumulate at the site of inflammation after intravenous administration. The particle size of the cationic and anionic liposomes was reduced by PEG modification; PEG liposomes can enhance dispersibility by forming a hydration layer. Optimizing the particle size would enable passive targeting as per the EPR effect.

The distribution in the body after the intravenous administration of each liposome to collagen-induced arthritis (CIA) model mice was examined. Figures 3(a) and 3(b) show the localization of liposomes, qualitatively evaluated using an in vivo imaging system, and Fig. 3(c) shows the fluorescence intensity of the foot (RA onset). A high clinical score indicates that inflammation is being promoted. Fluorescence at the site with a high clinical score means that liposomes are accumulated at the site of inflammation. The four types of liposomes were administered intravenously to CIA mice to evaluate the effects of liposome surface charge and PEG modification on the accumulation at inflammatory sites as shown in Fig. 3. The numbers on the paws are clinical scores.

PEG-modified liposomes showed a greater accumulation at the inflammatory sites than unmodified liposomes [Figs. 3(a) and 3(b)]. Figure 3(b) shows sarcoma with a high clinical score, and Fig. 3(c) shows that the fluorescence intensity of PEG-modified liposomes is four times higher than that of unmodified liposomes. Regarding surface charge, cationic and anionic

(a)

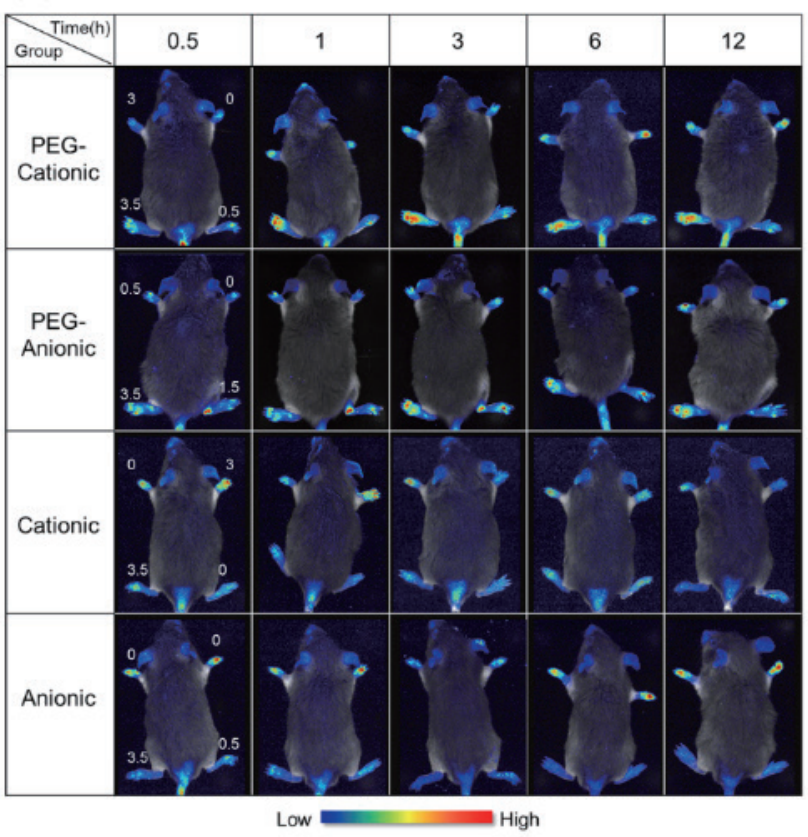

(b)

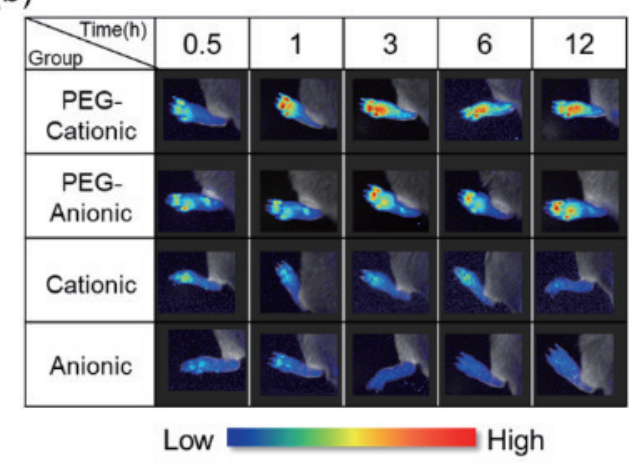

(c)

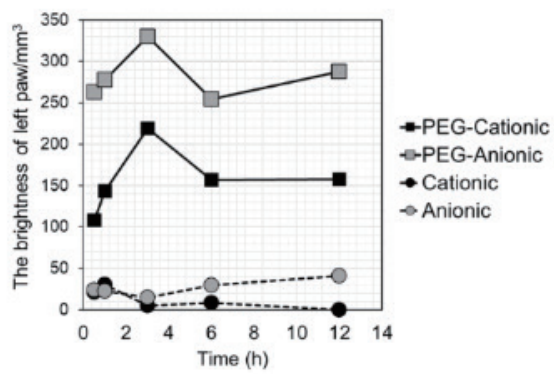

Fig. 3. (Color) Evaluation of PEG-modified liposome accumulation at inflammatory sites in CIA and healthy mice. (a) Accumulation of each liposome at the site of inflammation. The numbers indicate the clinical scores calculated according to certain criteria. (b) Enlarged images of the feet with a clinical score of 4.5. (c) Brightness measured at the accumulation sites based on the images in (b). This figure was published in "In vivo fluorescence imaging of passive inflammation site accumulation of liposomes via intravenous administration focused on their surface charge and PEG modification," Pharmaceutics, 13(1), 104 (2021), Hisako Ibaraki and Takanori Kanazawa et al. 
liposomes accumulated to the same extent at the site of inflammation (left leg; high clinical score). The semi-quantitative analysis shown in Fig. 1(c) indicates that PEG-anionic liposomes showed 2.5 times higher fluorescence intensity than PEG-cationic liposomes. These results indicate that upon intravenous administration, anionic PEG-modified liposomes most effectively accumulate at the site of inflammation.

The dextran sodium sulfate (DSS)-induced ulcerative colitis model has been widely used because of its simplicity and similarity to human ulcerative colitis. We evaluated the accumulation of intravenously administered liposomes in the colon of DSS-induced colitis mice by in vivo imaging.

The evaluation of liposome accumulation in the DSS-induced ulcerative colitis model mice showed results similar to those observed in the RA mice (Fig. 4). All four types of liposomes were administered intravenously to both DSS-induced and healthy mice. The colon was resected, and the accumulation of liposomes in the inflamed colon tissue was observed using an in vivo

(a)

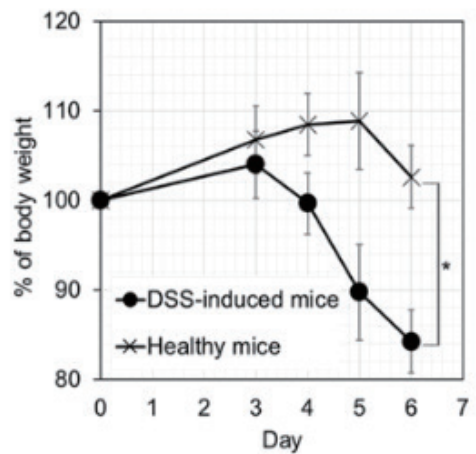

(c)

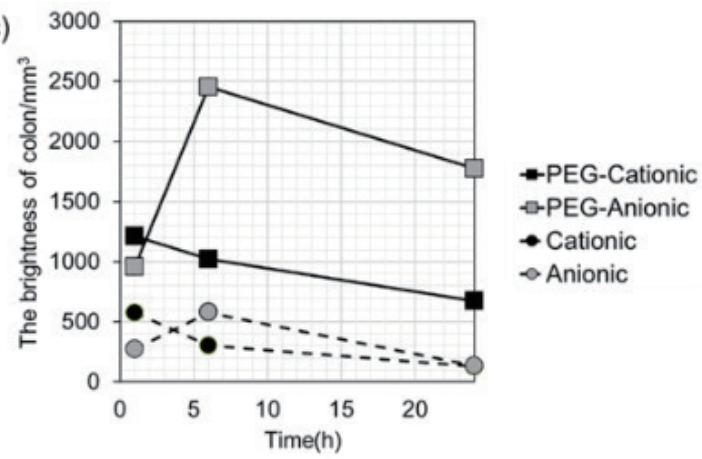

(b)

\begin{tabular}{|c|c|c|c|c|}
\hline \multicolumn{2}{|c|}{ Group $\quad$ Time(h) } & 1 & 6 & 24 \\
\hline \multirow{4}{*}{$\begin{array}{l}\text { DSS } \\
\text { mice }\end{array}$} & $\begin{array}{l}\text { PEG- } \\
\text { Cationic }\end{array}$ & i.:-innas & Dones...... is & 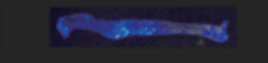 \\
\hline & $\begin{array}{l}\text { PEG- } \\
\text { Anionic }\end{array}$ & 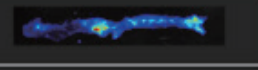 & 6) $x=-x$ & 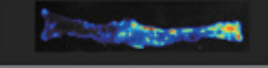 \\
\hline & Cationic & 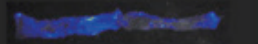 & 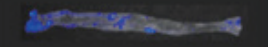 & 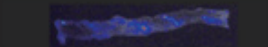 \\
\hline & Anionic & 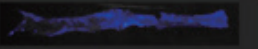 & 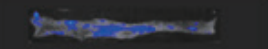 & 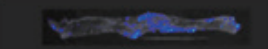 \\
\hline \multirow{4}{*}{$\begin{array}{l}\text { Healthy } \\
\text { mice }\end{array}$} & $\begin{array}{c}\text { PEG- } \\
\text { Cationic }\end{array}$ & 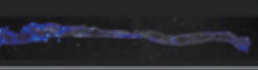 & 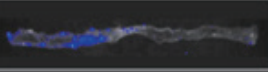 & exhents \\
\hline & $\begin{array}{l}\text { PEG- } \\
\text { Anionic }\end{array}$ & 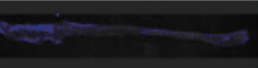 & bisea & 20 \\
\hline & Cationic & 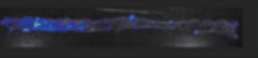 & 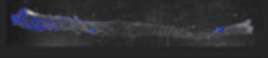 & - \\
\hline & Anionic & $\cos x-2 x=2$ & 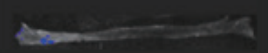 & \\
\hline
\end{tabular}

Low High

Fig. 4. (Color) Evaluation of inflammatory colon accumulation of liposomes with different physical characteristics after intravenous administration to DSS-induced mice. (a) Weight loss rate of mice orally administered DSS. Each bar represents mean \pm S.D. [DSS-induced UC model mice $(n=24)$, healthy mice $(n=15)$ ]. (b) Evaluation of in vivo images of the resected large intestine by intravenous administration of liposomes. (c) Average brightness calculated by Maestro 2.4 based on the images in (b). This figure was published in "In vivo fluorescence imaging of passive inflammation site accumulation of liposomes via intravenous administration focused on their surface charge and PEG modification,” Pharmaceutics, 13(1), 104 (2021) Hisako Ibaraki and Takanori Kanazawa et al. 
imaging system. In healthy mice, liposomes did not accumulate in the colon regardless of PEG modification or surface charge; in DSS-induced mice, unmodified liposomes did not fluoresce in the colon. In contrast, PEG-modified cationic and anionic liposomes accumulated in the inflamed colon $6 \mathrm{~h}$ after administration. The accumulation of cationic liposomes in the inflamed colon reached its peak $1 \mathrm{~h}$ after intravenous administration; however, the accumulation of anionic liposomes in the inflamed colon reached a maximum $3 \mathrm{~h}$ after administration. This may be due to the high retention of anionic liposomes in the blood, and similar results were obtained in CIA mice.

PEG modification prevented the phagocytosis of drugs, administered intravenously through nanocarriers, by RES, which decreased the RES trapping rate in the liver and spleen, and improved blood retention and accumulation at inflammatory sites. Although many nano-DDSs studied using the EPR effect have been reported to be effective for treating cancer, our results show that a phenomenon similar to the EPR effect occurs at inflammatory sites in non-tumor tissues, in terms of vascular permeability and neovascularization. Ren et al. reported that in an RA mouse model, intravenously administered anionic liposomes showed a greater accumulation than cationic liposomes at inflammatory sites. ${ }^{(22)}$ They also found that lightly charged liposomes accumulated more strongly than heavily charged liposomes at inflammatory sites. Lightly anionic liposomes have been reported to target arthritis most effectively and are best taken up by immunocompetent cells. ${ }^{(113)}$ The surface potential of our PEG-modified anionic liposomes was charged and similar results were obtained. Phagocytic cells, such as macrophages, can phagocytose liposomes having strong surface charge. In this way, the immune system at the site of inflammation is activated and deactivated. Thus, Figs. 3 and 4 show that anionic liposomes accumulate more effectively than cationic liposomes at the site of inflammation when administered intravenously.

We also assessed the intracellular uptake efficiency of PEG-modified liposomes in immunocompetent cells. Inflammatory diseases implicate numerous immunocytes, such as dendritic cells, macrophages, and T- and B-lymphocytes. Macrophages, in particular, are important in inflammatory disease progression. They are highly active at inflammation sites, produce copious proinflammatory cytokines, such as IL-6, IL-1 $\beta$, and TNF- $\alpha$, and trigger inflammatory responses. ${ }^{(114,115)}$ Nanoparticles deliver drugs to macrophages at the inflammation sites and thus these cells are important targets.

Intravenously administered PEG-anionic liposomes were the most efficacious in terms of in vivo accumulation in the inflammatory sites of tumors. Nevertheless, their intracellular uptake capacity was extremely low. ${ }^{(30)}$ PEG-cationic liposomes may effectively target inflammation sites. Moreover, to ensure there is a balance between internal and intracellular kinetics to successfully design liposomes for intravenous administration, it is important that they align with intracellular target kinetics, accumulate at inflammation sites after intravenous administration, and are readily absorbed by target macrophages. In fact, we previously confirmed that PEGmodified cationic polymeric micelles accumulated at the inflammation site, suppressed inflammatory cytokine production, and had high therapeutic efficacy after intravenous administration. $^{(116)}$ Therefore, our findings were reasonable. 


\section{Conclusion}

The effects of physical properties of liposomes on their biodistribution after topical (dermal) and systemic (intravenous) administration were comprehensively demonstrated. The charges were found to have effectiveness in the order cationic $>$ anionic $>$ neutral, with flexible carriers having higher intradermal permeability. The balance with biotoxicity suggests that anionic liposomes, such as DOPE/CHEMS liposomes, may be useful for treating skin conditions. For treating inflammatory diseases, we evaluated the accumulation of PEG-modified and unmodified, positively charged and negatively charged liposomes at inflammatory sites after intravenous administration to RA and ulcerative colitis model mice. The PEG-modified anionic liposomes showed the highest accumulation at the inflammatory site, and the distribution in the body depended on the PEG modification and charge. Although many unknowns remain about how the physical properties of liposomes affect intradermal permeability and their inflammatory site accumulation on topical and systemic administration, we have clarified some of these issues. Nanotechnology using liposomes is expected to contribute to drug therapy for various intractable dermatological and inflammatory diseases.

\section{Acknowledgments}

This work was supported in part by a Grant-in-Aid for Early-Career Scientists (18K14960) from the Japan Society for the Promotion of Science.

\section{References}

1 A. D. Bangham and R. W. Horne: J. Mol. Biol. 8 (1964) 660. https://doi.org/10.1016/s0022-2836(64)80115-7

2 A. D. Bangham, M. M. Standish, and J. C. Watkins: J. Mol. Biol. 13 (1965) 238. https://doi.org/10.1016/s00222836(65)80093-6

3 S. J. Singer and G. L. Nicolson: Science 175 (1972) 720. https://doi.org/10.1126/science.175.4023.720

4 A. Akinc, M. A. Maier, M. Manoharan, K. Fitzgerald, M. Jayaraman, S. Barros, S. Ansell, X. Du, M. J. Hope, T. D. Madden, B. L. Mui, S. C. Semple, Y. K. Tam, M. Ciufolini, D. Witzigmann, J. A. Kulkarni, R. van der Meel, and P. R. Cullis: Nat. Nanotechnol. 14 (2019) 1084. https://doi.org/10.1038/s41565-019-0591-y

5 M. W. Tenforde, W. H. Self, E. A. Naioti, A. A. Ginde, D. J. Douin, S. M. Olson, H. K. Talbot, J. D. Casey, N. M. Mohr, A. Zepeski, M. Gaglani, T. McNeal, S. Ghamande, N. I. Shapiro, K. W. Gibbs, D. C. Files, D. N. Hager, A. Shehu, M. E. Prekker, H. L. Erickson, M. N. Gong, A. Mohamed, D. J. Henning, J. S. Steingrub, I. D. Peltan, S. M. Brown, E. T. Martin, A. S. Monto, A. Khan, C. L. Hough, L. W. Busse, C. C. T. Lohuis, A. Duggal, J. G. Wilson, A. J. Gordon, N. Qadir, S. Y. Chang, C. Mallow, C. Rivas, H. M. Babcock, J. H. Kwon, M. C. Exline, N. Halasa, J. D. Chappell, A. S. Lauring, C. G. Grijalva, T. W. Rice, I. D. Jones, W. B. Stubblefield, and A. Baughman, K.y N, Womack, C. J, K. W. Hart, Lindsell, Y. Zhu, M, S. J. Schrag, Stephenson, M. Kobayashi, J. R. Verani, M.M Patel, IVY Network Investigators; IVY Network: MMWR: Morb. Mortal. Wkly. Rep. 70 (2021) 1156. https://doi.org/10.15585/mmwr.mm7034e2

6 J. L. Andresen and O. S. Fenton: MRS Bull. 14 (2021) 1. https://doi.org/10.1557/s43577-021-00169-2

7 E. Beltrán-Gracia, A. López-Camacho, I. Higuera-Ciapara, J. B. Velázquez-Fernández, and A. A. VallejoCardona: Cancer Nano. 10 (2019) 11. https://doi.org/10.1186/s12645-019-0055-y

8 D. Nayak and V. K. Tippavajhala: Iran. J. Pharm. Res. 20 (2021) 186. https://doi.org/10.22037/ ijpr.2020.112878.13997

9 W. Wu, Y. Lu, and J. Qi: Ther. Deliv. 6 (2015) 1239. https://doi.org/10.4155/tde.15.69

10 M. Feghhi, B. Sharif Makhmalzadeh, F. Farrahi, M. Akmali, and N. Hasanvand: Curr. Eye Res. 45 (2020) 1245. https://doi.org/10.1080/02713683.2020.1728777 
11 S. Honmane, A. Hajare, H. More, R. A. M. Osmani, and S. Salunkhe: J. Liposome Res. 29 (2019) 332. https:// doi.org/10.1080/08982104.2018.1531022

12 X. Zhang, J. Qi, Y. Lu, W. He, X. Li, and W. Wu: Nanomedicine 10 (2014) 167. https://doi.org/10.1016/j. nano.2013.07.011

13 M. Murata, K. Nakano, K. Tahara, Y. Tozuka, and H. Takeuchi: Eur. J. Pharm. Biopharm. 80 (2012) 340. https://doi.org/10.1016/j.ejpb.2011.10.011

14 R. Jijie, A. Barras, R. Boukherroub, and S. Szunerits: J. Mater. Chem. B 5 (2017) 8653. https://doi.org/10.1039/ C7TB02529G

15 K. Khezri, M. Saeedi, and S. M. Maleki Dizaj: Biomed. Pharmacother. 106 (2018) 1499. https://doi. org/10.1016/j.biopha.2018.07.084

16 A. Jose, S. Labala, K. M. Ninave, S. K. Gade, and V. V. K. Venuganti: AAPS PharmSciTech. 19 (2018) 166. https://doi.org/10.1208/s12249-017-0833-y

17 J. H. Senior: Crit. Rev. Ther. Drug Carrier Syst. 3 (1987) 123

18 J. Senior and G. Gregoriadis: FEBS Lett. 145 (1982) 109. https://doi.org/10.1016/0014-5793(82)81216-7

19 V. Torchilin: Adv. Drug Deliv. Rev. 63 (2011) 131. https://doi.org/10.1016/j.addr.2010.03.011

20 K. Maruyama: Adv. Drug Deliv. Rev. 63 (2011) 161. https://doi.org/10.1016/j.addr.2010.09.003

21 J. Park, Y. Choi, H. Chang, W. Um, J. H. Ryu, and I. C. Kwon: Theranostics 9 (2019) 8073. https://doi. org/10.7150/thno.37198

22 T. M. Allen and C. Hansen: Biochim. Biophys. Acta. 1068 (1991) 133. https://doi.org/10.1016/00052736(91)90201-i

23 H. Ren, Y. He, J. Liang, Z. Cheng, M. Zhang, Y. Zhu, C. Hong, J. Qin, X. Xu, and J. Wang: ACS Appl. Mater. Interfaces. 11 (2019) 20304. https://doi.org/10.1021/acsami.8b22693

24 B. J. Crielaard, T. Lammers, R. M. Schiffelers, and G. Storm: J. Controlled Release 161 (2012) 225. https://doi. org/10.1016/j.jconrel.2011.12.014

25 J. P. Botero Aguirre, and A. M. Restrepo Hamid: Cochrane Database Syst. Rev. 23 (2015) CD010481. https:// doi.org/10.1002/14651858.CD010481.pub2

26 Y. Li, H. An, X. Wang, P. Wang, F. Qu, Y. Jiao, K. Zhang, and Q. Liu: Nano Res. 11 (2018) 1038. https://doi. org/10.1007/s12274-017-1719-8

27 G. Arias-Alpizar, L. Kong, R. C. Vlieg, A. Rabe, P. Papadopoulou, M. S. Meijer, S. Bonnet, S. Vogel, J. van Noort, A. Kros, and F. Campbell: Nat. Commun., Link. 11 (2020) 3638. https://doi.org/10.1038/s41467-02017360-9

28 A. Ranalli, M. Santi, L. Capriotti, V. Voliani, D. Porciani, F. Beltram, and G. Signore: Bioconjug. Chem. 28 (2017) 627. https://doi.org/10.1021/acs.bioconjchem.6b00701

29 Q. Yao, L. Kou, Y. Tu, and L. Zhu: Trends Pharmacol. Sci. 39 (2018)766. https://doi.org/10.1016/j. tips.2018.06.003

30 H. Ibaraki, T. Kanazawa, C. Oogi, Y. Takashima, and Y. Seta: J. Drug Deliv. Sci. Tech. 50 (2019) 155. https:// doi.org/10.1016/j.jddst.2019.01.028

31 H. Ibaraki, A. Takeda, N. Arima, N. Hatakeyama, Y. Takashima, Y. Seta, and T. Kanazawa: Pharmaceutics 13 (2021) 104.https://doi.org/10.3390/pharmaceutics13010104

32 P. K. Working, M. S. Newman, S. K. Huang, E. Mayhew, J. Vaage, and D. D. Lasic: J. Liposome Res. 4 (1994) 667. https://doi.org/10.3109/08982109409037065

33 E. A. Forssen and M. E. Ross: J. Liposome Res. 4 (1994) 481. https://doi.org/10.3109/08982109409037058

34 S. Phuphanich, B. Maria, R. Braeckman, and M. Chamberlain: J. Neuro-Oncol. 81 (2007) 201. https://doi. org/10.1007/s11060-006-9218-X

35 C. E. Swenson, W. R. Perkins, P. Roberts, and A. S. Janoff: The Breast 10 (2001) 1. https://doi.org/10.1016/ S0960-9776(01)80001-1

36 U. Bulbake, S. Doppalapudi, N. Kommineni, and W. Khan: Liposomal Formulations Clin. Use: An Updated Rev., Pharm. 9 (2017) 12. https://doi.org/10.3390/pharmaceutics9020012

37 J. A. Silverman and S. R. Deitcher: Cancer Chemother. Pharmacol. 71 (2013) 555. https://doi.org/10.1007/ s00280-012-2042-4

38 D. J. A. Crommelin, P. v. Hoogevest, and G. Storm: J. Contr. Release 318 (2020) 256. https://doi.org/10.1016/j. jconrel.2019.12.023

39 https://www.accessdata.fda.gov/drugsatfda docs/nda/2013/0196270rig1s060.pdf (accessed 24 September 2021).

40 M. Alam and C. T. Hartrick: Pain Pract. 5 (2005) 349. https://doi.org/10.1111/j.1533-2500.2005.00048.x

41 B. M. Ilfeld, E. R. Viscusi, A. Hadzic, H. S. Minkowitz, M. D. Morren, J. Lookabaugh, and G. P. Joshi: Reg. Anesthesia Pain Med. 40 (2015) 572. https://doi.org/10.1097/AAP.0000000000000283 
42 L. S. S. Guo, R. M. Fielding, D. D. Lasic, R. L. Hamilton, and D. Mufson: Int. J. Pharm. 75 (1991) 45. https:// doi.org/10.1016/0378-5173(91)90249-N

43 J. Adler-Moore and R. T. Proffitt: J. Antimicrob. Chemother. 49 (2002)21. https://doi.org/10.1093/jac/49. suppl 1.21

44 A. Akinc, M. A. Maier, M. Manoharan, K. Fitzgerald, M. Jayaraman, S. Barros, S. Ansell, X. Du, M. J. Hope, T. D. Madden, B. L. Mui, S. C. Semple, Y. K. Tam, M. Ciufolini, D. Witzigmann, J. A. Kulkarni, R. v. d. Meel, and P. R. Cullis: Nat. Nanotechnol. 14 (2019) 1084. https://doi.org/10.1038/s41565-019-0591-y

45 Y.-C. Chen, H.-F. Cheng, Y.-C. Yang, and M.-K. Yeh: Micro and Nanotechnologies for Biotechnology, Ed. S.G. Stanciu (IntechOpen Ltd., London, UK, 2016) Chap. 4. https://doi.org/10.5772/63453

46 P. A. Bovier: Expert Rev. Vaccines 7 (2008) 1141. https://doi.org/10.1586/14760584.7.8.1141

47 https://www.ema.europa.eu/en/documents/assessment-report/spikevax-previously-covid-19-vaccine-modernaepar-public-assessment-report en.pdf (accessed 24 September 2021).

48 Y.Gao, K. Yang, A. N. Shelling, and Z. Wu: Encyclopedia 1 (2021) 773. https://doi.org/10.3390/ encyclopedia1030059

49 A. Samad, Y. Sultana, and M. Aqil: Curr. Drug Deliv. 4 (2007) 297. https://doi.org/10.2174/156720107782151269

50 S. Sun, M. Wang, K. A. Alberti, A. Choy, and Q. Xu: Nanomedicine 9 (2013) 849. https://doi.org/10.1016/j. nano.2013.01.006

51 A. J. Verkleij: Biochim. Biophys. Acta. 779 (1984) 43. https://doi.org/10.1016/0304-4157(84)90003-0

52 S. M. Cho, H. Y. Lee, and J.-C. Kim: Korean J. Chem. Eng. 25 (2008) 390. https://doi.org/10.1007/s11814-0080066-6

53 J. J. Sudimack, W. Guo, W. Tjarks, and R. J. Lee: Biochim. Biophys. Acta. 1564 (2002) 31. https://doi. org/10.1016/s0005-2736(02)00399-1

54 J. Y. Park, H. Choi, J. S. Hwang, J. Kim, and I. S. Chang: J. Cosmet. Sci. 59 (2008) 1390.

55 I. Canton and G. Battaglia: Chem. Soc. Rev. 41 (2012) 2718. https://doi.org/10.1039/c2cs15309b

56 J. D. Bos and M. M. Meinardi: Exp. Dermatol. 9 (2000) 165. https://doi.org/10.1034/j.16000625.2000.009003165.x

57 S. N. Andrews, E. Jeong, and M. R. Prausnitz: Pharm. Res. 30 (2013) 1099. https://doi.org/10.1007/s11095-0120946-7

58 J. Chen, W. L. Lu, W. Gu, S. S. Lu, Z. P. Chen, and B. C. Cai: Expert Opin. Drug Deliv. 10 (2013) 845. https:// doi.org/10.1517/17425247.2013.779252

59 T. Liu, M. Chen, J. Fu, Y. Sun, C. Lu, G. Quan, X. Pan, and C. Wu: Acta Pharm. Sin. B 11 (2021) 2326. https:// doi.org/10.1016/j.apsb.2021.03.003

60 K. Saepang, S. K. Li, and D. Chantasart: Pharm. Res. 38 (2021) 1187. https://doi.org/10.1007/s11095-021-03055$\underline{3}$

61 B. E. Polat, W. M. Deen, R. Langer, and D. Blankschtein: J. Controlled Release 158 (2012) 250. https://doi. org/10.1016/j.jconrel.2011.11.008

62 H. Ibaraki, T. Kanazawa, Y. Takashima, H. Okada, and Y. Seta: Molecules 21 (2016) E1279 250. https://doi. org $/ 10.3390 /$ molecules 21101279

63 H. Ibaraki, T. Kanazawa, Y. Takashima, H. Okada, and Y. Seta: Int. J. Pharm. 542 (2018) 213. https://doi. org/10.1016/j.ijpharm.2018.03.026

64 M. Kong, H. Park, C. Feng, L. Hou, X. Cheng, and X. Chen: Carbohydr. Polym. 94 (2013) 634. https://doi. org/10.1016/j.carbpol.2013.01.09164

65 T. Rattanapak, K. Young, T. Rades, and S. Hook: J. Pharm. Pharmacol. 64 (2012) 1560. https://doi.org/10.1111/ j.2042-7158.2012.01535.x

66 G. M. El Maghraby, B. W. Barry, and A. C. Williams: Eur. J. Pharm. Sci. 34 (2008) 203. https://doi.org/10.1016/j. ejps.2008.05.002

67 M. Sala, R. Diab, A. Elaissari, and H. Fessi: Int. J. Pharm. 535 (2018) 1. https://doi.org/10.1016/j. ijpharm.2017.10.046

68 Y. Zhai, and G. Zhai: J. Controlled Release 193 (2014) 90. https://doi.org/10.1016/j.jconrel.2014.05.054

69 P. L. Honeywell-Nguyen, H. W. W. Wouter Groenink, A. M. de Graaff, and J. A. Bouwstra: J. Controlled Release 90 (2003) 243. https://doi.org/10.1016/s0168-3659(03)00202-5

70 R. R. Hood, E. L. Kendall, M. Junqueira, W. N. Vreeland, Z. Quezado, J. C. Finkel, and D. L. DeVoe: PLOS ONE 9 (2014) 92978. https://doi.org/10.1371/journal.pone.0092978

71 D. S. Mandlik and S. K. Mandlik: Immunopharmacol. Immunotoxicol. 43 (2021) 105. https://doi.org/10.1080/0 $\underline{8923973.2021 .1889583}$

72 J. Duplessis, C. Ramachandran, N. Weiner, and D. G. Müller: Int. J. Pharm. 103 (1994) 277. https://doi. org/10.1016/0378-5173(94)90178-3 
73 D. D. Verma, and A. Fahr: J. Controlled Release 97 (2004) 55. https://doi.org/10.1016/j.jconrel.2004.02.028

74 Y. P. Fang, Y. B. Huang, P. C. Wu, and Y. H. Tsai: Eur. J. Pharm. Biopharm. 73 (2009) 391. https://doi. org/10.1016/j.ejpb.2009.07.011

75 D. Van der Merwe, J. D. Brooks, R. Gehring, R. E. Baynes, N. A. Monteiro-Riviere, and J. E. Riviere: Toxicol. Sci. 89 (2006) 88. https://doi.org/10.1093/toxsci/kfj014

76 B. Baroli, M. G. Ennas, F. Loffredo, M. Isola, R. Pinna, and M. A. López-Quintela: J. Invest. Dermatol. 127 (2007) 1701. https://doi.org/10.1038/sj.jid.5700733

77 S. Villasmil-Sánchez, W. Drhimeur, S. C. Ospino, A. M. Rabasco Alvarez, and M. L. González-Rodríguez: Drug Dev. Ind. Pharm. 36 (2010) 666. https://doi.org/10.3109/03639040903419640

78 S. Kitagawa and M. Kasamaki: Chem. Pharm. Bull. (Tokyo) 54 (2006) 242. https://doi.org/10.1248/cpb.54.242

79 A. Gillet, F. Lecomte, P. Hubert, E. Ducat, B. Evrard, and G. Piel: Eur. J. Pharm. Biopharm. 79 (2011) 43. https://doi.org/10.1016/j.ejpb.2011.01.011

80 C. Sinico, M. Manconi, M. Peppi, F. Lai, D. Valenti, and A. M. Fadda: J. Controlled Release 103 (2005) 123. https://doi.org/10.1016/j.jconrel.2004.11.020

81 S. M. Moghimi, and A. C. Hunter: Pharm. Res. 18 (2001) 1. https://doi.org/10.1023/A:1011054123304

82 G. Cevc, A. Schätzlein, and H. Richardsen: Biochim. Biophys. Acta 1564 (2002) 21. https://doi.org/10.1016/ s0005-2736(02)00401-7

83 G. Cevc, and G. Blume: Biochim. Biophys. Acta. 1663 (2004) 61. https://doi.org/10.1016/j.bbamem.2004.01.006.

84 S. Kumar, P. Sahdev, O. Perumal, and H. Tummala: Mol. Pharm. 9 (2012) 1320. https://doi.org/10.1021/ mp200594z

85 S. T. Kim, K. M. Lee, H. J. Park, S. E. Jin, W. S. Ahn, and C. K. Kim: J. Gene Med. 11 (2009) 26. https://doi. org/10.1002/jgm.1268

86 E. K. Oh, S. E. Jin, J. K. Kim, J. S. Park, Y. Park, and C. K. Kim: Eur. J. Pharm. Sci. 44 (2011) 149. https://doi. org/10.1016/j.ejps.2011.07.003

87 M. J. Tsai, Y. B. Huang, J. W. Fang, Y. S. Fu, and P. C. Wu: PLOS ONE 10 (2015) 0131026. https://doi. org/10.1371/journal.pone.0131026

88 P. Karande, A. Jain, and S. Mitragotri: Nat. Biotechnol. 22 (2004) 192. https://doi.org/10.1038/nbt928

89 NIH Autoimmune Diseases Coordinating Committee: Autoimmune Diseases Research Plan, https://www. niaid.nih.gov/sites/default/files/adccfinal.pdf (accessed 24 September 2021).

90 F. Magro and F. Portela: BioDrugs. 24 (2010) 3. https://doi.org/10.2165/11586290-000000000-00000

91 Y. Huang, J. Guo, and S. Gui: Eur. J. Pharm. Sci. 125 (2018) 232. https://doi.org/10.1016/j.ejps.2018.10.009

92 L. Klareskog, A. I., and S. Catrin: Lancet 373 (2009). 21. https://doi.org/10.1016/S0140-6736(09)60008-8

93 H. Kaplon and J. M. Reichert: mAbs 11 (2019) 219. https://doi.org/10.1080/19420862.2018.1556465

94 W. J. Sandborn, G. Van Assche, W. Reinisch, J. F. Colombel, G. D’Haens, D. C. Wolf, M. Kron, M. B. Tighe, A. Lazar, and R. B. Thakkar: Gastroenterology 142 (2012) 257. https://doi.org/10.1053/j.gastro.2011.10.032

95 S. V. Patel and D. A. Khan: Immunol. Allergy Clin. N. Am. 37 (2017) 397. https://doi.org/10.1016/j. iac.2017.01.012

96 Entyvio: https://www.entyvio.com/cost (accessed 24 September 2021).

97 N. Zahin, R. Anwar, D. Tewari, T. Kabir, A. Sajid, B. Mathew, S. Uddin, L. Aleya, and M. M. Abdel-Daim: Environ. Sci. Pollut. Res. 27 (2019) 19151.

98 M. A. Kandeil, E. T. Mohammed, K. S. Hashem, L. Aleya, and M. M. Abdel-Daim: Environ. Sci. Pollut. Res. Int. 27 (2020) 19169. https://doi.org/10.1007/s11356-019-05514-2

99 A. Rahdar, S. Sargazi, M. S. Amiri, P. K. Sharma, N. Bhalla: Sens. Biosens. Res. 32 (2021) 100417. https://doi. org/10.1016/j.sbsr.2021.100417

100 M. Boshtam, S. Asgary, S. Kouhpayeh, L. Shariati, and H. Khanahmad: Inflammation 40 (2017) 340. https:// doi.org/10.1007/s10753-016-0477-1

101 H. Nemati, M. H. Ghahramani, R. Faridi-Majidi, B. Izadi, G. Bahrami, S. H. Madani, and G. Tavoosidana: J. Controlled Release 268 (2017) 259. https://doi.org/10.1016/j.jconrel.2017.10.034

102 S. Taurin, H. Nehoff, and K. Greish: J. Controlled Release 164 (2012) 265. https://doi.org/10.1016/j. jconrel.2012.07.013

103 H. Maeda, J. Wu, T. Sawa, Y. Matsumura, and K. Hori: J. Controlled Release 65 (2000) 271. https://doi. org/10.1016/s0168-3659(99)00248-5

104 T. Ishihara, E. Hayashi, S. Yamamoto, C. Kobayashi, Y. Tamura, R. Sawazaki, F. Tamura, K. Tahara, T. Kasahara, T. Ishihara, M. Takenaga, K. Fukuda, and T. Mizushima: J. Controlled Release 197 (2015) 97. https://doi.org/10.1016/j.jconrel.2014.10.029

105 J. Fang, H. Yin, L. Liao, H. Qin, F. Ueda, K. Uemura, K. Eguchi, G. Y. Bharate, and H. Maeda: J. Controlled Release 223 (2016) 188-. https://doi.org/10.1016/j.jconrel.2015.12.049 
106 M. Hayder, M. Poupot, M. Baron, D. Nigon, C. O. Turrin, A. M. Caminade, J. P. Majoral, R. A. Eisenberg, J. J. Fournié, A. Cantagrel, R. Poupot, and J. L. Davignon: Sci. Transl. Med. 3 (2011) 81ra35. https://doi.org/10.1126/ scitranslmed.3002212

107 F. Alexis, E. Pridgen, L. K. Molnar, and O. C. Farokhzad: Mol. Pharm. 5 (2008) 505. https://doi.org/10.1021/ $\underline{\mathrm{mp} 800051 \mathrm{~m}}$

108 A. K. Iyer, G. Khaled, J. Fang, and H. Maeda: Drug Discov. Today 11 (2006) 812. https://doi.org/10.1016/j. drudis.2006.07.005

109 N. Oku and Y. Namba: Crit. Rev. Ther. Drug Carrier Syst. 11 (1994) 231.

110 Y. Yamamoto, Y. Nagasaki, Y. Kato, Y. Sugiyama, and K. Kataoka: J. Controlled Release 77 (2001) 27. https:// doi.org/10.1016/s0168-3659(01)00451-5

111 D. Liu, A. Mori, and L. Huang: Biochim. Biophys. Acta Biomembr. 1066 (1991) 159. https://doi. org/10.1016/0005-2736(91)90182-8

112 N. Cloutier, A. Paré, R. W. Farndale, H. R. Schumacher, P. A. Nigrovic, S. Lacroix, and E. Boilard: Blood 120 (2012) 1334. https://doi.org/10.1182/blood-2012-02-413047

113 R. L. Hong, C. J. Huang, Y. L. Tseng, V. F. Pang, S. T. Chen, J. J. Liu, and F. H. Chang: Clin. Cancer Res. 5 (1999) 3645.

114 Y. Pei and Y. Yeo: J. Controlled Release 240 (2016) 202. https://doi.org/10.1016/j.jconrel.2015.12.014

115 J. Zhang, Y. Zhao, T. Hou, H. Zeng, D. Kalambhe, B. Wang, X. Shen, and Y. Huang: J. Controlled Release 320 (2020) 363. https://doi.org/10.1016/j.jconrel.2020.01.047

116 T. Kanazawa, T. Endo, N. Arima, H. Ibaraki, Y. Takashima, and Y. Seta: Int. J. Pharm. 515 (2016) 315. https:// doi.org/10.1016/j.ijpharm.2016.10.033

\section{About the Authors}

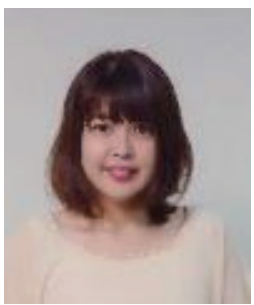

Hisako Ibaraki received her B.S. and Ph.D. degrees from Tokyo University of Pharmacy and Life Sciences (TUPLS), Japan, in 2014 and 2019, respectively. She has been working as a research associate at TUPLS since 2014. Her research interests are in drug delivery systems for nucleic acid drugs to treat cancer and skin diseases. (Ibaraki@toyaku.ac.jp)

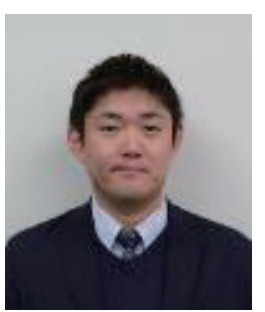

Takanori Kanazawa received his B.S., M.S., and Ph.D. degrees from Tokyo University of Pharmacy and Life Sciences (TUPLS), Japan, in 2004, 2006, and 2010, respectively. He was an assistant professor at TUPLS from 2011 to 2016 and a lecturer at Nihon University, Japan, from 2017 to 2020. Since 2020, he has been an associate professor at University of Shizuoka, Japan. His research interests are in pharmaceutical engineering and drug delivery systems based on nanoengineering. (t.kanazawa@u-shizuoka-ken.ac.jp) 